\title{
PRELIMINARY VALUATION OF "Y" AND "V"-TRELLISED CANOPIES FOR MECHANICAL HARVESTING OF PLUMS, SWEET CHERRIES AND SOUR CHERRIES FOR THE FRESH MARKET
}

\author{
Jacek RABCEWICZ, Augustyn MIKA, Zbigniew BULER*, Paweł BIAŁKOWSKI \\ Research Institute of Horticulture \\ Konstytucji 3 Maja 1/3, 96-100 Skierniewice, Poland \\ Received: June 2017; Accepted: November 2017
}

\begin{abstract}
Plums, sweet cherry, and sour cherry trees were spaced $4.5 \mathrm{~m} \times 1.5 \mathrm{~m}$ to be trained to "Y" and "V"trellising systems for mechanical harvesting, with a canopy contact harvester, attending to obtain fruits meeting the requirements of the fresh fruit market. The applied trellising systems were compared with the standard central leader system at the same spacing. The most of trellised trees grew less vigorously than the standard trees, and after 3 years of training, the trees were suitable for mechanical harvesting with the harvester designed at the Research Institute of Horticulture in Skierniewice. The trellised trees were able to set as many fruitlets as those grown in the form of central leader and gave a comparable yield, but differences between cultivars were significant. Light interception in the third year after planting was lower for trees of sour cherry and plum growing in the "Y"- $20^{\circ}$ and "V" in comparison to the trees with central leader. Illumination of trellised canopies at the level of 0.7 and $1.5 \mathrm{~m}$ was the most favorable in "V" system when compared to control and "Y" training systems. Cost of construction for the trellising systems of stone fruits calculated per 1 ha was two times higher when compared with the standard system.
\end{abstract}

Key words: stone fruits, trellising systems, mechanical harvesting, illumination

\section{INTRODUCTION}

During recent years, much progress has been done in mechanical harvesting of soft fruits produced for industrial processing. At present, several species of fruit bushes, sour cherries, olives, plums, and other species are mechanically harvested (Brown et al. 1983; Wawrzyńczak et al. 1998; Jiménez et al. 2011; Ferguson et al. 2012; Mika et al. 2012). Experimental works are still being conducted to improve harvesting technology (Ampatzidis et al. 2012; Larbi $\&$ Karkee 2014; He et al. 2015). Mechanical fruit harvesting is mostly performed by means of trunk shakers, but it has several disadvantages, particularly fruit bruising and low effectiveness of fruit collection (Castro-García et al. 2012).

Trials with mechanical harvesting of stone fruits destined for the fresh market have revealed that the tree architecture is very important. Trees should have only one layer of branches resembling the shape of the letter "Y" or "V". Day et al. (2013) compared these forms with standard tall trees and found that standard trees were only slightly more productive than low trees.

Mechanical harvesting of plums for industrial purposes has already been solved. Diener et al. (1982) reported that in Western Virginia, a harvester that was able to harvest both large conventional trees and size-controlled trees planted at high density had been constructed. The harvester, with two trunk shakers, had a very high harvesting efficiency of 6-7 th $h^{-1}$. Fruits were not suitable for the fresh market because of bruising. Mika et al. (2012) demonstrated mechanical harvesting of densely planted plum trees trained to the central leader, and pruned by the renewal method, with a self-propelled straddle canopy contact harvester. The harvesting efficiency was $2-3 t \cdot h^{-1}$, with $90-95 \%$ effectiveness. 
The harvester was designed for collecting plums for industrial processing, but the quality of small-sized plums and prunes was so good that, after sorting, $80 \%$ was suitable for the fresh market. In another trial, an effort was made to harvest mechanically dessert quality plums from trees planted at high density and trellised as a horizontal canopy (shaped like the letter T) (Mika et al. 2016). The trees were suitable for harvesting with a small tractor-driven canopy-contact harvester, but the growth of the trees was not satisfactory.

The majority of sour cherry fruits are produced for industrial purposes because the fresh market of this fruit is limited. On small plantations, sour cherry fruits destined for processing are harvested manually. On large plantations, they are harvested by shaking the tree trunk. The fruits are collected on canvas sheets or conveyers. The quality of mechanically harvested sour cherries is worse than that of those that are handpicked; however, they are accepted for juice and jam processing. The frozenfood industry prefers manually harvested fruits (Mika et al. 2011).

With an increasing standard of living, the demand for fresh sweet cherry fruit is increasing in Europe and the United States. The fruits should be large, attractive, tasty, and available for a long time (in Europe for 10 weeks). Sweet cherry production is increasing in Europe, the United States, Canada, and Chile. In all these regions, the shortage of manual labor for hand harvesting may be an obstruction in the production. To overcome the problem, intensive research work was undertaken to solve the problem (Peterson \& Wolford 2001; Peterson 2005; Seavert \& Whiting 2011; Ampatzidis et al. 2012; Ampatzidis \& Whiting 2013; Larbi \& Karkee 2014; He et al. 2015).

Peterson and Wolford (2001) designed a cherry orchard for mechanical harvesting and solved the problem of harvesting fruits. Mechanical cherry harvesting might be improved by loosening the fruit-pedicel attachment by applying Ethrel 7-14 days before harvesting (Peterson 2005 after Bukovac et al. 1971).

Canopy architecture has a major effect on both manual and mechanical harvesting efficiency. To be suitable for mechanical harvesting, a cherry tree should have 2-3 limbs for each side in the "Y"-system. The limbs should be short and stiff, inclined at $45-60^{\circ}$ to the horizontal (Peterson 2005).

One of the best architectures compatible with the harvesting system is the "Y"-trellis system. The highest harvesting rate was obtained with a $45-60^{\circ}$ "Y"-trellis system with 6-8 scaffold branches.

Recent trials on harvesting plums and sour cherries for industrial processing with the straddle, canopy contact harvester constructed at the Research Institute of Horticulture in Skierniewice, revealed that the harvester is able to collect fruit with 80-90\% efficiency at the rate of $3-4 \mathrm{t} \cdot \mathrm{h}^{-1}$. However, it appeared that the standard central leader canopy is not adequate for harvesting fresh market fruit because the falling fruits pass too long a distance from the canopy structure to the grabbing system, and some percentage of the fruits suffer bruising. Our attempt to train trees with only one layer of horizontal branches (T system) resulted in uneven shoot growth because of the phenomenon of negative gravimorphism. Shoots in the canopy center were too strong, and those outside the canopy were too weak.

The main target of the experimental work was to create a new orchard architecture and to test the suitability of "Y" and "V"-trellised canopy for mechanical harvesting of plums, sweet cherries, and sour cherries produced for the fresh market.

\section{MATERIALS AND METHODS}

In March 2014, an experimental plot consisted of plum, prune, sweet cherry, and sour cherry trees was planted at the Institute of Horticulture (InHort) in Skierniewice, in an area of 0.75 ha. The following trees were planted: two plum cultivars, 'Record' and 'Empress' grafted on semi-dwarf rootstock 'Wangenheim Prune'; one prune cv. 'Common Prune' grafted on Prunus myrobalan; two sweet cherry cultivars, 'Lapins' grafted on 'Colt' and 'Kordia' grafted on Mazzard F 12/1; four sour cherry cultivars, 'English Morello', 'Nefris', 'Kelleris 16', and 'Debreceni Bötermo' grafted on Prunus mahaleb rootstock. The planting distance of $4.5 \mathrm{~m}$ between rows was uniform for all the cultivars. The spacing in the row varied according to the expected tree vigor. Weakly growing sour cherry trees were spaced 
$1.5 \mathrm{~m}$ apart; moderately growing plum and sweet cherry $2.0 \mathrm{~m}$; vigorously growing sweet cherry $2.5 \mathrm{~m}$. The distance from the fruit stem to the grabbing unit was planned for $0.7-1.5 \mathrm{~m}$. To create conditions for continuous moving of the harvester, each cultivar was planted in a separate row $160 \mathrm{~m}$ long. The row of plum trees grafted on semi dwarf rootstocks contained 80 , plum trees grafted on vigorous rootstocks 72 trees and sour cherry trees contained 94 trees. Sweet cherry cultivar 'Lapins' contained 69 trees and cultivar 'Kordia' 32 trees in the row. Each tree in the row was treated as a replication.

There were four methods of tree training:

1. Tree training to "Y" canopy with branches at $20^{\circ}$ to the horizontal.

2. Tree training to "Y" canopy with branches at $30^{\circ}$ to the horizontal.

3. Tree training to "V" canopy with branches at $45^{\circ}$ to the horizontal.

4. Control: tree training to central leader canopy with the leader tied to a pole.

Each cultivar was represented by at least three objects with $20^{\circ}, 30^{\circ}$, or $45^{\circ}$ and combination control but not all treatments were applied for each cultivars (details given in the Tables).

To erect the trellising support, galvanized metal profiles $60 \mathrm{~mm} \times 60 \mathrm{~mm} \times 4 \mathrm{~mm}$ were mounted in the ground to a depth of $0.8 \mathrm{~m}$ at a distance of $10 \mathrm{~m}$ apart. The first support in the row was reinforced in the ground with concrete. On the vertical support, at the height of $0.8 \mathrm{~m}$, metal arms were mounted aslant at $20^{\circ}$ and $30^{\circ}$. Four wires were stretched between these arms along the row at a distance of 0.5 and $1.0 \mathrm{~m}$ from the row center line on both sides. The trellising made it possible to create a continuous canopy $2 \mathrm{~m}$ wide and $50 \mathrm{~m}$ long. To obtain the "V" system, metal poles were driven into the ground, $10 \mathrm{~m}$ apart, aslant at $45^{\circ}$, and two wires were stretched in each row. Stakes angled at $45^{\circ}$ were used to support each tree. The control trees, trained to the central leader, were tied to metal stakes driven $0.8 \mathrm{~m}$ into the ground at each tree to a height of $2.5 \mathrm{~m}$. The control trees were trained to the standard method. In the first year, shoots were lightly tipped to stimulate vigorous growth. The leader shoot was tied vertically to the pole and the side shoots were directed in May to an aslant or horizontal position with pins (clips) to form wide angles. Such treatment was repeated in the second year on trees that required such a correction. After planting, pruning of the trees designed to " $\mathrm{V}$ " and "Y" trellising was nearly the same as for the control trees, but the lowest laterals up to a height of $0.8 \mathrm{~m}$ were removed, because they would interfere with the work of the harvester. In the first year, it was necessary to bend and tie 4-10 summer shoots to the wires, and even more in the second year. In the third year, some additional bendings was indispensable, mainly on sweet cherry trees.

On these plots, over a period of three years, tree growth vigor was assessed by taking annual measurements of the trunk's diameter, converted later into the trunk's cross-sectional area (TCSA). The measurements also included the height and span of the crowns, the number of new shoots in specific length classes, and the percentage of flower buds on annual and older shoots. For the three years of tree vegetation, the structure of the canopies was studied. In the autumn, the new shoots were counted, measured and described in terms of the way in which they branched. In the spring, the inflorescences were counted on the shoots classified at $20-\mathrm{cm}$ intervals in order to determine the relationship between shoot length and flower bud density. Two 3-year-old branches coming off the leader were chosen for this purpose.

To evaluate light relation within the trees, solar irradiation was measured in the third year of the trial, in August, with a hand solarimeter (Sun Scan Probe type SS1, produced by Delta-T Devices Ltd., Burwell, Cambridge, England). Measurements were done only on sunny days during noon hours. The results of irradiation were converted to the percentage of light within the tree canopy in relation to the total radiation from the hemisphere. Light interception was evaluated with tube solarimeter (Sun Scan Probe type SS1, produced by Delta-T Devices Ltd., Burwell, Cambridge, England) laid out for two summer weeks crosswise on the ground between tree rows. Interception was calculated as the difference between total light irradiation minus irradiation at the ground level. Light distribution was recorded at 1.5 and $0.7 \mathrm{~m}$ of tree canopies. 
The direct cost of establishing a trellised orchard in relation to a standard orchard was calculated by adding the cost of soil cultivation, fertilization, cost of trees, supporting system, and trellised wires. The cost of the experimental plots was calculated per 1 ha.

The results were evaluated statistically and presented in the form of tables and graphs. The results were statistically elaborated using analysis of variance separately for each cultivar, followed by means separation with Duncan's multiple-range ttest at $\mathrm{P}<0.05$.

\section{RESULTS AND DISCUSSION}

Fruit trees trellised in the "V" or "Y" systems to facilitate mechanical harvesting showed a different pattern of growth than the control central-leader trees as a result of negative gravimorphism. In the natural tree growth, the main shoots are directed to grow upright or aslant, as a result of the phenomenon of negative gravimorphism. Auxins are concentrated more in the lower than in the upper layer, so the lower layers are stimulated to induce intensive growth and push the shoot up to an upright or aslant position (Costes \& Guédon 1997). Apical buds on the shoot take dominance over lateral buds. They are formed larger and better developed. Owing to the domination of apical buds, they start to develop first and produce stronger annual shoots (Jankiewicz 1972). When trellised shoots are bent to a horizontal position, the negative gravimorphism stimulates the growth of buds at the base of the shoot instead of the apex. The most vigorous shoots appear near the tree trunk, in the center of the tree canopy, and the weakest at its periphery. This causes irregular development of the canopy trained horizontally (Mika et al. 2016). To avoid such disadvantages, we assumed shoot positioning at $20^{\circ}, 30^{\circ}$, and $45^{\circ}$ to the horizontal. In the result, the shoots trellised at $20^{\circ}$ produced the most intensive growth in the center of the tree canopy, those trellised at $30^{\circ}$ showed less growth, and at $45^{\circ}$, the effect of negative geomorphology was hardly noticeable (Table 1 ). This phenomenon plays an important role in trellising fruit trees for mechanical harvesting. Mechanical harvesting is best facilitated when branches are in a horizontal position because the falling fruits have the shortest way to travel from the branches to the catching unit. Increasing the angle of the fruiting layer makes this distance longer. At $45^{\circ}$, it is difficult to harvest dessert fruit. On the other hand, trees trained with branches close to the horizontal have uneven growth and require the removal of strong shoots from the center of tree canopy every year.

Table 1. Effect of branch positioning on negative morphology expressed as total shoot growth (m) in the center of tree canopy (2016)

\begin{tabular}{lccc}
\hline \multirow{2}{*}{ Species } & \multicolumn{3}{c}{ Tree training system } \\
\cline { 2 - 4 } & "Y" & "Y" & "Y" \\
& system $20^{\circ}$ & system $30^{\circ}$ & \\
\hline Plums & $13.6 \mathrm{a} \pm 0.75^{*}$ & $7.2 \mathrm{~b} \pm 0.62$ & $1.8 \mathrm{c} \pm 0.31$ \\
$\begin{array}{l}\text { Sour cherries } \\
14.0 \mathrm{a} \pm 0.82\end{array}$ & $9.4 \mathrm{~b} \pm 0.54$ & $6.6 \mathrm{c} \pm 0.67$ \\
$\begin{array}{l}\text { Sweet cher- } \\
\text { ries }\end{array}$ & $2.6 \mathrm{a} \pm 0.16$ & $3.2 \mathrm{a} \pm 0.52$ & $1.6 \mathrm{~b} \pm 0.16$ \\
\hline
\end{tabular}

* Means in each line indicated by the same letter do not differ significantly according to the Duncan test at $p=0.05$; means \pm SD.

The three years of training revealed a tendency of the trellised trees to weaker growth in comparison with the control ones. The effects were the most distinct at shoot bending to the degree $30^{\circ}$. Among the nine experimental genotypes, in six significant differences were found in the TCSA index between the control trees and those in the trellising system (Table 2). The significance concerned plum 'Common Prune' at "Y" $20^{\circ}$, three of four sour cherry cultivars at " $\mathrm{Y}$ " $30^{\circ}$, and sweet cherry 'Lapins' at "V" $45^{\circ}$ and all types of banding for 'Kordia'. The total shoot growth of some cultivars was also negatively affected by bending. The growth was decreased by "V" system in plum 'Record', sweet cherry 'Kelleris 16', and both sour cherry cultivars. The "Y" systems reduced shoot growth of plum 'Common Prune' and all sweet and sour cherry cultivars. The plum 'Empress' was not affected (Table 3). Diverse planting density in the rows had no influence on tree growth. Reduced tree growth is caused by the effect of shoot bandings on the transporting tissues in shoots that are damaged or translocated, retarding the transport of minerals to the shoots and inhibiting translocation of photosynthetic products. In the case of vigorous trees, shoot bending can promote early bearing (Mika 1969). 
Table 2. Trunk cross-sectional area $\left(\mathrm{cm}^{2}\right)$ in the third year after planting (2016)

\begin{tabular}{|c|c|c|c|c|}
\hline \multirow{2}{*}{ Cultivar } & \multicolumn{4}{|c|}{ Tree training system } \\
\hline & control & "Y" system $20^{\circ}$ & "Y" system $30^{\circ}$ & "V" system \\
\hline \multicolumn{5}{|c|}{ Plums } \\
\hline 'Record' & $16.1 \mathrm{a} \pm 1.56^{*}$ & $18.3 \mathrm{a} \pm 1.37$ & - & $18.7 \mathrm{a} \pm 2.94$ \\
\hline 'Empress' & $9.8 \mathrm{a} \pm 0.89$ & - & $8.8 \mathrm{a} \pm 0.81$ & $9.3 \mathrm{a} \pm 0.97$ \\
\hline 'Common Prune' & $23.5 \mathrm{a} \pm 2.22$ & $17.5 \mathrm{~b} \pm 1.11$ & $20.1 \mathrm{ab} \pm 1.68$ & - \\
\hline \multicolumn{5}{|c|}{ Sour cherries } \\
\hline 'English Morello' & $9.5 \mathrm{ab} \pm 1.26$ & $10.7 \mathrm{a} \pm 1.20$ & $6.1 \mathrm{~b} \pm 0.73$ & - \\
\hline 'Kelleris 16' & $16.0 \mathrm{a} \pm 0.61$ & - & $11.4 \mathrm{~b} \pm 1.08$ & $14.2 \mathrm{ab} \pm 2.03$ \\
\hline 'Nefris' & $10.5 \mathrm{a} \pm 0.56$ & $8.8 \mathrm{ab} \pm 0.89$ & $7.2 \mathrm{~b} \pm 1.33$ & - \\
\hline 'Debreceni Bötermo' & $15.7 \mathrm{a} \pm 1.80$ & $13.8 \mathrm{a} \pm 0.62$ & - & $14.2 \mathrm{a} \pm 0.84$ \\
\hline \multicolumn{5}{|c|}{ Sweet cherries } \\
\hline 'Lapins' & $33.3 \mathrm{a} \pm 1.96$ & $31.0 \mathrm{a} \pm 1.36$ & $34.4 \mathrm{a} \pm 2.34$ & $23.6 \mathrm{~b} \pm 3.63$ \\
\hline 'Kordia' & $50.1 \mathrm{a} \pm 2.43$ & $37.1 \mathrm{~b} \pm 1.74$ & $42.4 \mathrm{~b} \pm 2.09$ & $41.4 \mathrm{~b} \pm 3.05$ \\
\hline
\end{tabular}

* For explanations see Table 1.

Table 3. Total shoot growth $\left(\mathrm{m} \cdot\right.$ tree $\left.^{-1}\right)$ for years $2014-2016$

\begin{tabular}{|c|c|c|c|c|}
\hline \multirow{2}{*}{ Cultivar } & \multicolumn{4}{|c|}{ Tree training system } \\
\hline & control & "Y" system $20^{\circ}$ & "Y" system $30^{\circ}$ & "V" system \\
\hline \multicolumn{5}{|c|}{ Plums } \\
\hline 'Record' & $35.5 \mathrm{a} \pm 0.45^{*}$ & $36.7 \mathrm{a} \pm 0.64$ & - & $21.1 \mathrm{~b} \pm 1.32$ \\
\hline 'Empress' & $15.9 \mathrm{a} \pm 0.66$ & - & $11.3 \mathrm{a} \pm 0.53$ & $12.8 \mathrm{a} \pm 0.28$ \\
\hline 'Common Prune' & $65.4 \mathrm{a} \pm 1.62$ & $51.3 \mathrm{~b} \pm 3.63$ & $71.1 \mathrm{a} \pm 2.52$ & - \\
\hline \multicolumn{5}{|c|}{ Sour cherries } \\
\hline 'English Morello' & $48.9 \mathrm{a} \pm 1.57$ & $45.5 \mathrm{a} \pm 2.67$ & $20.3 \mathrm{~b} \pm 1.34$ & - \\
\hline 'Kelleris 16' & $66.6 \mathrm{a} \pm 2.24$ & - & $39.2 \mathrm{~b} \pm 0.85$ & $44.9 b \pm 3.39$ \\
\hline 'Nefris' & $56.6 \mathrm{a} \pm 1.60$ & $34.8 \mathrm{~b} \pm 1.97$ & $26.3 \mathrm{c} \pm 1.13$ & - \\
\hline 'Debreceni Bötermo' & $53.7 \mathrm{a} \pm 0.70$ & $34.3 \mathrm{~b} \pm 2.97$ & - & $32.3 \mathrm{~b} \pm 1.63$ \\
\hline \multicolumn{5}{|c|}{ Sweet cherries } \\
\hline 'Lapins' & $38.8 \mathrm{a} \pm 1.41$ & $28.9 \mathrm{~b} \pm 2.12$ & $35.6 \mathrm{a} \pm 1.86$ & $19.1 \mathrm{c} \pm 0.58$ \\
\hline 'Kordia' & $82.4 \mathrm{a} \pm 1.60$ & $55.7 \mathrm{c} \pm 2.76$ & $71.0 \mathrm{~b} \pm 2.79$ & $55.4 \mathrm{c} \pm 4.80$ \\
\hline
\end{tabular}

* For explanations see Table 1.

Table 4. Number of flower buds per tree in the second year after planting (2015)

\begin{tabular}{|c|c|c|c|c|}
\hline \multirow{2}{*}{ Cultivar } & \multicolumn{4}{|c|}{ Tree training system } \\
\hline & control & "Y" system $20^{\circ}$ & "Y" system $30^{\circ}$ & "V" system \\
\hline \multicolumn{5}{|c|}{ Plums } \\
\hline 'Record' & $172.8 \mathrm{a} \pm 19.63^{*}$ & $106.8 \mathrm{~b} \pm 21.95$ & - & $181.2 \mathrm{a} \pm 13.60$ \\
\hline 'Empress' & $131.6 \mathrm{a} \pm 5.23$ & - & $60.7 b \pm 9.98$ & $125.8 \mathrm{a} \pm 11.82$ \\
\hline \multicolumn{5}{|c|}{ Sour cherries } \\
\hline 'Kelleris 16' & $182.1 \mathrm{a} \pm 22.62$ & - & $253.3 \mathrm{a} \pm 22.24$ & $102.7 b \pm 16.95$ \\
\hline 'Nefris' & $118.1 b \pm 6.24$ & $152.0 \mathrm{a} \pm 11.90$ & $127.9 \mathrm{ab} \pm 10.80$ & - \\
\hline 'Debreceni Bötermo' & $39.0 \mathrm{~b} \pm 6.30$ & $40.3 b \pm 9.24$ & - & $103.5 \mathrm{a} \pm 4.15$ \\
\hline \multicolumn{5}{|c|}{ Sweet cherries } \\
\hline 'Lapins' & $24.6 \mathrm{~b} \pm 2.27$ & $23.4 \mathrm{~b} \pm 3.57$ & $20.6 b \pm 3.49$ & $56.8 \mathrm{a} \pm 4.08$ \\
\hline 'Kordia' & $88.3 \mathrm{a} \pm 4.82$ & $69.5 \mathrm{ab} \pm 9.71$ & $87.9 \mathrm{a} \pm 6.49$ & $53.9 \mathrm{~b} \pm 7.30$ \\
\hline
\end{tabular}

\footnotetext{
* For explanations see Table 1.
} 
Table 5. Number of fruitlets per tree in the second year after planting (2015)

\begin{tabular}{|c|c|c|c|c|}
\hline \multirow{2}{*}{ Cultivar } & \multicolumn{4}{|c|}{ Tree training system } \\
\hline & control & "Y" system $20^{\circ}$ & "Y" system $30^{\circ}$ & "V" system \\
\hline \multicolumn{5}{|c|}{ Plums } \\
\hline 'Record' & $7.1 \mathrm{~b} \pm 0.90^{*}$ & $5.9 \mathrm{~b} \pm 3.38$ & - & $21.2 \mathrm{a} \pm 1.94$ \\
\hline ‘Empress’' & $27.2 \mathrm{~b} \pm 5.11$ & - & $21.2 \mathrm{~b} \pm 4.13$ & $59.6 \mathrm{a} \pm 5.87$ \\
\hline 'Common Prune' & $10.2 \mathrm{a} \pm 1.58$ & $9.5 \mathrm{a} \pm 3.67$ & $6.8 \mathrm{a} \pm 3.03$ & - \\
\hline \multicolumn{5}{|c|}{ Sour cherries } \\
\hline 'Kelleris 16' & $205.4 \mathrm{a} \pm 28.26$ & - & $272.7 \mathrm{a} \pm 36.72$ & $77.2 \mathrm{~b} \pm 22.32$ \\
\hline 'Nefris' & $98.6 \mathrm{a} \pm 11.45$ & $99.5 \mathrm{a} \pm 11.56$ & $70.7 b \pm 3.83$ & - \\
\hline 'Debreceni Bötermo' & $18.7 \mathrm{~b} \pm 1.59$ & $18.7 \mathrm{~b} \pm 3.91$ & - & $64.8 \mathrm{a} \pm 16.04$ \\
\hline \multicolumn{5}{|c|}{ Sweet cherries } \\
\hline 'Lapins' & $19.2 \mathrm{~b} \pm 4.48$ & $15.6 \mathrm{~b} \pm 5.64$ & $13.1 \mathrm{~b} \pm 0.87$ & $53.4 \mathrm{a} \pm 5.85$ \\
\hline 'Kordia' & $37.9 \mathrm{a} \pm 7.73$ & $32.7 \mathrm{ab} \pm 1.74$ & $27.1 \mathrm{ab} \pm 8.32$ & $19.6 b \pm 3.68$ \\
\hline
\end{tabular}

* For explanations see Table 1.

Table 6. Percentage of flower buds on one-year-old and two-year-old shoots in the third year after planting (2016)

\begin{tabular}{|c|c|c|c|c|c|c|c|c|}
\hline \multirow{3}{*}{ Cultivar } & \multicolumn{8}{|c|}{ Tree training system } \\
\hline & \multicolumn{2}{|c|}{ control } & \multicolumn{2}{|c|}{ "Y" system $20^{\circ}$} & \multicolumn{2}{|c|}{ "Y" system $30^{\circ}$} & \multicolumn{2}{|c|}{ "V" system } \\
\hline & $\begin{array}{l}\text { one-year- } \\
\text { old }\end{array}$ & $\begin{array}{l}\text { two-year- } \\
\text { old }\end{array}$ & $\begin{array}{l}\text { one-year- } \\
\text { old }\end{array}$ & $\begin{array}{l}\text { two-year- } \\
\text { old }\end{array}$ & $\begin{array}{c}\text { one-year- } \\
\text { old }\end{array}$ & $\begin{array}{l}\text { two-year- } \\
\text { old }\end{array}$ & $\begin{array}{c}\text { one-year- } \\
\text { old }\end{array}$ & $\begin{array}{l}\text { two-year } \\
\text { old }\end{array}$ \\
\hline \multicolumn{9}{|c|}{ Plums } \\
\hline 'Record' & 77 & 23 & 72 & 28 & - & - & 70 & 30 \\
\hline 'Empress' & 77 & 23 & - & - & 70 & 30 & 72 & 28 \\
\hline 'Common Prune' & 52 & 48 & 38 & 62 & 41 & 59 & - & - \\
\hline \multicolumn{9}{|c|}{ Sour cherries } \\
\hline 'English Morello' & 87 & 13 & 84 & 16 & 85 & 15 & - & - \\
\hline 'Kelleris 16' & 83 & 17 & - & - & 90 & 10 & 80 & 20 \\
\hline 'Nefris' & 92 & 8 & 93 & 7 & 91 & 9 & - & - \\
\hline 'Debreceni Bötermo' & 72 & 28 & 58 & 42 & - & - & 73 & 27 \\
\hline \multicolumn{9}{|c|}{ Sweet cherries } \\
\hline 'Lapins' & 31 & 69 & 45 & 55 & 43 & 57 & 45 & 55 \\
\hline 'Kordia' & 52 & 48 & 57 & 43 & 56 & 44 & 56 & 44 \\
\hline
\end{tabular}

Table 7. Percentage of fruitlets on one-year-old and two-year-old shoots in the third year after planting (2016)

\begin{tabular}{|c|c|c|c|c|c|c|c|c|}
\hline \multirow{3}{*}{ Cultivar } & \multicolumn{8}{|c|}{ Tree training system } \\
\hline & \multicolumn{2}{|c|}{ control } & \multicolumn{2}{|c|}{ "Y" system $20^{\circ}$} & \multicolumn{2}{|c|}{ "Y" system $30^{\circ}$} & \multicolumn{2}{|c|}{ "V" system } \\
\hline & $\begin{array}{c}\text { one-year- } \\
\text { old }\end{array}$ & $\begin{array}{l}\text { two-year- } \\
\text { old }\end{array}$ & $\begin{array}{l}\text { one-year- } \\
\text { old }\end{array}$ & $\begin{array}{l}\text { two-year- } \\
\text { old }\end{array}$ & $\begin{array}{l}\text { one-year- } \\
\text { old }\end{array}$ & $\begin{array}{l}\text { two-year- } \\
\text { old }\end{array}$ & $\begin{array}{l}\text { one-year- } \\
\text { old }\end{array}$ & $\begin{array}{c}\text { two-year- } \\
\text { old }\end{array}$ \\
\hline \multicolumn{9}{|c|}{ Plums } \\
\hline 'Record' & 83 & 17 & 68 & 32 & - & - & 20 & 80 \\
\hline 'Empress' & 61 & 39 & - & - & 63 & 37 & 84 & 16 \\
\hline 'Common Prune' & 55 & 45 & 40 & 60 & 33 & 67 & - & - \\
\hline \multicolumn{9}{|c|}{ Sour cherries } \\
\hline 'English Morello' & 97 & 3 & 96 & 4 & 97 & 3 & - & - \\
\hline 'Kelleris 16' & 89 & 11 & - & - & 97 & 3 & 93 & 7 \\
\hline 'Nefris' & 99 & 1 & 97 & 3 & 98 & 2 & - & - \\
\hline 'Debreceni Bötermo' & 95 & 5 & 88 & 12 & - & - & 93 & 7 \\
\hline \multicolumn{9}{|c|}{ Sweet cherries } \\
\hline 'Lapins' & 54 & 46 & 37 & 63 & 29 & 71 & 41 & 59 \\
\hline 'Kordia' & 53 & 47 & 70 & 30 & 54 & 46 & 72 & 28 \\
\hline
\end{tabular}


Table 8. Total yield for 2015-2016 $\left(\mathrm{kg} \cdot \mathrm{tree}^{-1}\right)$, manually harvested

\begin{tabular}{|c|c|c|c|c|}
\hline \multirow{2}{*}{ Cultivar } & \multicolumn{4}{|c|}{ Tree training system } \\
\hline & control & "Y" system $20^{\circ}$ & "Y" system $30^{\circ}$ & "V" system \\
\hline \multicolumn{5}{|c|}{ Plums } \\
\hline 'Record' & $3.5 \mathrm{c} \pm 0.22 *$ & $8.6 \mathrm{a} \pm 0.22$ & - & $6.7 b \pm 0.22$ \\
\hline 'Empress’' & $5.7 b \pm 0.22$ & - & $6.8 \mathrm{a} \pm 0.22$ & $7.0 \mathrm{a} \pm 0.22$ \\
\hline 'Common Prune' & $4.6 \mathrm{a} \pm 0.15$ & $3.3 b \pm 0.16$ & $3.2 \mathrm{~b} \pm 0.15$ & - \\
\hline \multicolumn{5}{|c|}{ Sour cherries } \\
\hline 'English Morello' & $6.0 \mathrm{a} \pm 0.22$ & $4.9 \mathrm{~b} \pm 0.22$ & $4.2 \mathrm{~b} \pm 0.22$ & - \\
\hline 'Kelleris 16' & $5.9 \mathrm{a} \pm 0.22$ & - & $5.8 \mathrm{a} \pm 0.22$ & $3.9 b \pm 0.22$ \\
\hline \multicolumn{5}{|c|}{ Sweet cherries } \\
\hline 'Lapins' & $1.0 \mathrm{~b} \pm 0.15$ & $2.4 \mathrm{a} \pm 0.16$ & $2.6 \mathrm{a} \pm 0.16$ & $1.2 \mathrm{~b} \pm 0.22$ \\
\hline 'Kordia' & $4.7 \mathrm{a} \pm 0.18$ & $3.4 b \pm 0.18$ & $3.6 \mathrm{~b} \pm 0.18$ & $2.0 \mathrm{c} \pm 0.18$ \\
\hline
\end{tabular}

* For explanations see Table 1 .

In our trial, we were not able to prove the stimulating effect of shoot bending on fruit bud formation, probably because of the moderate growth of all stone fruit trees. The "Y"-training system significantly decreased the number of flower buds in the plum cultivars in the second year of planting (Table 4). For sour cherry, the above effect was unclear. The highest number of flower buds in sweet cherry "Lapins' was at "V" system, and this treatment was the worst for cv. 'Kordia'. The number of fruitlets, which is the best indicator of potential tree productivity was mostly proportional to that of flower buds (Table 5). A trellised tree must be pruned by the renewal method to obtain young flexible shoots in the working space of harvester rods. For this reason, the percentage of fruit buds on one-year-old and twoyear old shoots was recorded (Table 6). In all the treatments and most cultivars (exception was plum 'Common Prune' and sweet cherries), most of the fruit buds were on one-year-old shoots. The distribution of fruitlets was almost the same (Table 7). The first crop (Table 8) was too low to evaluate the productivity systems. The "Y" and "V"-trellising systems significantly increased the yield of plums 'Record' and 'Empress' and sweet cherry 'Lapins'.

Light interception was not high (Table 9) because the tree canopies were small. "V" system reduced light interception in plums and sour cherries. "Y" $20^{\circ}$ system reduced light interception in sour cherry and plum trees (Table 9). According to Jackson and Palmer (1974), it should amounts to more than $30 \%$ of the light coming into the orchard.
Table 9. Percentage of light intercepted by plum and sour cherry trees in summer 2016

\begin{tabular}{lccc}
\hline \multirow{2}{*}{ Species } & \multicolumn{3}{c}{ Tree training system } \\
\cline { 2 - 4 } & control & $\begin{array}{c}\text { "Y" } \\
\text { system } 20^{\circ}\end{array}$ & $\begin{array}{c}\text { "V" } \\
\text { system }\end{array}$ \\
\hline Plums & 29.7 & 23.4 & 14.5 \\
Sour cherries & 21.6 & 14.7 & 14.0 \\
\hline
\end{tabular}

Light distribution (Table 10) measured for plum trees in the third year (2016) in the upper part of tree canopy $1.5 \mathrm{~m}$ above the ground and in the lower part at $0.7 \mathrm{~m}$ was the same for central leader and "V" trained system and significantly lower for the "Y" $20^{\circ}$ system. Illumination of sour cherry canopies was the best at "V" system at the both levels of measurement. Illumination at $1.5 \mathrm{~m}$ of sweet cherry trees was equal in all systems of training, but at $0.7 \mathrm{~m}$, "V" system caused more illumination than "Y" $20^{\circ}$ and standard leader system. At the $0.7 \mathrm{~m}$, "V" system allowed most illumination for all plant species. The lowest values from $10.7 \%$ to $12.4 \%$ at "Y" system of sour cherries and plum trees were because of insufficient illumination according to Jackson 1970 and Jackson and Palmer 1974.

The cost of establishing the orchard with the supporting system was twice as high as for a standard orchard. The main value in the high cost of the trellised orchard was the supporting system. It was constructed out of high-quality galvanized steel. In practice, it could be constructed at a lower cost, but even so a trellised orchard would be at least $50 \%$ more expensive than a standard orchard. 
Table 10. Light distribution within tree canopy on two levels as a percentage of the light above tree canopy in the third year after planting (2016)

\begin{tabular}{|c|c|c|c|}
\hline \multirow{2}{*}{$\begin{array}{l}\text { Measuring level } \\
\text { (m) }\end{array}$} & \multicolumn{3}{|c|}{ Tree training system } \\
\hline & control & "Y" system $20^{\circ}$ & "V" system \\
\hline \multicolumn{4}{|c|}{ Plum cv. 'Record' } \\
\hline 0.7 & $22.9 \mathrm{a} \pm 39.83^{*}$ & $12.4 b \pm 18.32$ & $25.1 \mathrm{a} \pm 37.61$ \\
\hline 1.5 & $55.5 \mathrm{a} \pm 47.48$ & $30.8 b \pm 29.32$ & $51.5 \mathrm{a} \pm 62.22$ \\
\hline \multicolumn{4}{|c|}{ Sour cherry cv. 'Debreceni Bötermo' } \\
\hline 0.7 & $13.2 \mathrm{~b} \pm 22.68$ & $10.7 \mathrm{~b} \pm 13.09$ & $30.8 \mathrm{a} \pm 43.80$ \\
\hline 1.5 & $55.6 \mathrm{~b} \pm 77.54$ & $63.7 \mathrm{~b} \pm 43.81$ & $70.7 \mathrm{a} \pm 43.14$ \\
\hline \multicolumn{4}{|c|}{ Sweet cherry cv. 'Lapins' } \\
\hline 0.7 & $36.8 \mathrm{~b} \pm 50.35$ & $45.2 \mathrm{~b} \pm 43.84$ & $62.9 \mathrm{a} \pm 45.00$ \\
\hline 1.5 & $52.4 \mathrm{a} \pm 62.08$ & $65.7 \mathrm{a} \pm 61.44$ & $63.9 \mathrm{a} \pm 77.89$ \\
\hline
\end{tabular}

* Means indicated by the same letter do not differ significantly according to the Duncan test at $\mathrm{p}=0.05$; means $\pm \mathrm{SD}$. Results were analyzed separately for species and levels of canopies.

When growing fruit trees in a trellised system, one should expect some alteration in shoot growth, in comparison with the natural tree shape, because of negative geotropism. The problem to solve is to obtain uniform growth. Uniform shoot growth will be achieved when branches are not trained horizontally but aslant.

The supporting system for trellised canopies appeared to be three times as expensive as that for the standard system. The direct costs of establishing 1 ha of a trellised orchard compared to a standard, intensive orchard are as follows:

\section{Trellised orchard of stone fruits (in PLN)}

Soil cultivation, farm manure, mineral fertilizers $=$ 4000

Trees $1480 \times 15$ PLN $=22200$

Irrigation system $=20000$

Supporting system of galvanized steel $=73546$

Galvanized wires $=3872$

Total $=123618$

\section{Standard orchard (in PLN)}

Soil cultivation, farm manure, mineral fertilization $=4000$

Trees $1666 \times 15$ PLN $=24990$

Irrigation system $=20000$

Supporting system (metal galvanized poles and wires) $=15990$

Total $=64980$

\section{CONCLUSIONS}

A full evaluation of the productivity of the studied models of tree canopies will be possible after reaching full fruiting. From the point of suitability for mechanical harvesting with the harvester that was developed in the Research Institute of Horticulture in Skierniewice, it appears that at least "Y" system will be sufficiently useful, but this conclusion can be modified in the following years because of fruit yield at the full cropping and under mechanical harvesting. The "V" system assured the best light distribution within tree canopy. Mechanical harvesting will be performed from the year 2017 onward.

\section{Acknowledgment}

This publication was produced under the project: "Development of the technology of cultivation and mechanical harvesting dessert fruit: plums, sour cherries and sweet cherries" - contract number PBS2/A8/21/2013. The project was co-financed by the National Centre for Research and Development (NCBR) within the framework of the Applied Research Programme (PBS).

\section{REFERENCES}

Ampatzidis Y.G., Zhang Q., Whiting M. 2012. Comparing the efficiency of future harvest technologies for sweet cherry. Acta Horticulturae 965: 195-198. DOI: 10.17660/actahortic.2012.965.26. 
Ampatzidis Y.G., Whiting M.D. 2013. Training system affects sweet cherry harvest efficiency. HortScience 48(5): 547-555.

Brown G.K., Marshall D.E., Tennes B.R., Booster D.E., Chen P., Garrett R.E. et al. 1983. Status of harvest mechanization of horticultural crops. ASAE Publication, St. Joseph, Michigan, 78 p.

Castro-García S., Blanco Roldán G.L., Jiménez-Jiménez F., Gil-Ribes J.A., Ferguson L., Glozer K. et al. 2012. Preparing Spain and California table olive industries for mechanical harvesting. Acta Horticulturae 965: 29-40. DOI: 10.17660/actahortic.2012.965.1.

Costes E., Guédon Y. 1997. Modeling of sylleptic branching on one-year-old trunks of apple cultivars. Journal of the American Society for Horticultural Science 122: 53-62.

Day K.R., Johnson R.S., DeJong T.M. 2013. Developing a pedestrian plum orchard: the role of tree form, density, and height. Acta Horticulturae 985: 175180. DOI: 10.17660/actahortic.2013.985.21.

Diener R.G., Elliott K.C., Nesselroad P.E., Adams R.E., Blizzard S.H., Ingle M., Singha S. 1982. The West Virginia University tree fruit harvester. Journal of Agricultural Engineering Research 27: 191-200. DOI: 10.1016/0021-8634(82)90061-0.

Ferguson L., Glozer K., Crisosto C., Rosa U.A., CastroGarcía S., Fichtner E.J. et al. 2012. Improving canopy contact olive harvester efficiency with mechanical pruning. Acta Horticulturae 965: 83-87. DOI: 10.17660/actahortic.2012.965.8.

He L., Zhou J., Zhang Q., Karkee M. 2015. Evaluation of multipass mechanical harvesting on 'Skeena' sweet cherries trained to Y-trellis. HortScience 50(8): 1178-1182.

Jackson J.E. 1970. Aspects of light climate within apple orchards. Journal of Applied Ecology 7: 207-216. DOI: $10.2307 / 2401373$.

Jackson J.E., Palmer J.W. 1974. Light interception and distribution in relation to intensive orchard systems. Proceedings of the $19^{\text {th }}$ International Horticultural Congress, Warsaw, Abstracts, 1B: 539.

Jankiewicz L.S. 1972. A cybernetic model of growth correlations in young apple trees. Biologia Plantarum 14(1): 52-61. DOI: 10.1007/bf02920902.
Jiménez M.R., Rallo P., Suárez M.P., Morales-Sillero A.M., Casanova L., Rapoport H.F. 2011. Cultivar susceptibility and anatomical evaluation of table olive fruit bruising. Acta Horticulturae 924: 419-424. DOI: 10.17660/actahortic.2011.924.53.

Larbi P.A., Karkee M. 2014. Effects of orchard characteristics and operator performance on harvesting rate of a mechanical sweet cherry harvester. GSTF Journal on Agricultural Engineering 1(1): 1-11. DOI: $10.5176 / 2345-7848 \_1.1 .1$.

Mika A. 1969. Effects of shoot-bending and pruning on growth and fruit bud formation in young apple trees. Horticultural Research 9: 93-102.

Mika A., Buler Z., Rabcewicz J., Białkowski P., Konopacka D. 2016. Horizontal canopy for plums mechanically harvested in continuous motion. Acta Scientiarum Polonorum, Hortorum Cultus 15(6): 49-59.

Mika A., Wawrzyńczak P., Buler Z., Konopacka D., Konopacki P., Krawiec A. et al. 2012. Mechanical harvesting of plums for processing with a continuously moving combine harvester. Journal of Fruit and Ornamental Plant Research 20(1): 29-42. DOI: 10.2478/v10290-012-0003-y.

Mika A., Wawrzyńczak P., Buler Z., Krawiec A., Białkowski P., Michalska B. et al. 2011. Results of experiments with densely-planted sour cherry trees for harvesting with a continuously moving combine harvester. Journal of Fruit and Ornamental Plant Research 19(2): 31-40.

Peterson D.L. 2005. Harvest mechanization progress and prospects for fresh market quality deciduous tree fruits. HortTechnology 15(1): 72-75.

Peterson D.L., Wolford S.D. 2001. Mechanical harvester for fresh market quality stemless sweet cherries. Transactions of the ASAE 44: 481-485. DOI: $10.13031 / 2013.6103$.

Seavert C.F., Whiting M.D. 2011. Comparing the economics of mechanical and traditional sweet cherry harvest. Acta Horticulturae 903: 725-730. DOI: 10.17660/actahortic.2011.903.101.

Wawrzyńczak P., Cianciara Z., Krzewiński J. 1998. A new concept of mechanical harvest of sour cherries. Journal of Fruit and Ornamental Plant Research 6(3-4): 123-128. 